This is an author produced version of a paper published in Environmental Impact Assessment Review. This paper has been peer-reviewed but does not include the final journal pagination

Citation for the published paper:

Persson, J. (2006) Theoretical reflections on the connection between environmental assessment methods and conflicts . Environmental Impact Assessment Review. Volume: 26 Number: 7, pp 605-613. http://dx.doi.org/10.1016/j.eiar.2006.04.005

Access to the published version may require journal subscription. Published with permission from: Elsevier Ltd.

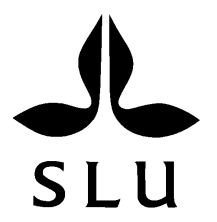

Epsilon Open Archive http://epsilon.slu.se 


\title{
Theoretical reflections on the connection between environmental assessment methods and conflict
}

\author{
Jesper Persson \\ Department of Landscape Management and Horticultural Technology, Swedish University of Agricultural Sciences, \\ P.O. Box 66, SE-230 53 Alnarp, Sweden
}

Received 1 July 2005; received in revised form 1 April 2006; accepted 1 April 2006

Available online 23 June 2006

\begin{abstract}
Today there is a great variety of methods for evaluating the environmental impact of plans, programs and projects. But which of these methods should planners and managers choose? This theoretical article explores the connection between conflicts, communication and rationality in assessment methods. It focuses on the form (rationality) and substance of communication, i.e. what we should communicate about. The outcome supports the view that environmental assessments should be based on value- and interest-focused thinking, following a teleological ethic, when goals, alternatives and compensations are to be developed and impacts evaluated.
\end{abstract}

Keywords: Environmental assessment; Rationality; Conflict; Communication; Method; Value

\section{Conflicts: different magnitudes but often undesired}

Planning and management are heterogeneous activities as regards both their theory and practice. However, in reflecting upon contemporary professional practice, I wish that there were more discussion of issues such as values and democracy. Generally, most environmental evaluations focus on a set of environmental parameters assumed to be effected by a plan or project. I claim that the main problem with this approach is not the correctness of the scientific models predicting the effects on the environment, even if the belief in the 'objectivity' of science is sometimes exaggerated. The main problem is that a focus on parameters (especially in aggregated methods) obscures stakeholders' interests and conflicts, and hinders creative problem-solving. Instead, when conducting an environmental assessment, I would like to see people's values and interests

E-mail address: jesper.persson@1t.slu.se. 
involved as the point of departure. The aim of this article is to explore the connection between environmental assessment methods and conflict, in terms of concepts as rationality and communication. The objectives are to contribute to the discussion on the development and use of environmental assessment methods, but also to promote methods that follows a teleologic ethic and focus on stakeholders values and interests in order to more successfully address conflicts.

Both globally and locally, we observe numerous conflicts related to our perception of environmental values or interests. Some examples may start with an obvious case. Environmental activists generally see themselves as moral citizens who, through violent or nonviolent actions, try to protect our world from environmental degradation and to restrain societies' violation of animal rights. Governments, on the other hand, regard it as their responsibility to protect their citizens from illegal activities, with the result that we have a number of environmental conflict areas. As an instance of activism, the North American Animal Liberation Front's Press Office states that its organization alone was responsible for property damage of $\$ 17.3$ million during 2001. Its Earth section, which focuses on actions against logging and habitat destruction by damaging agencies of urban sprawl and development, golf courses or industrial equipment, was responsible for about \$7.8 million (North American Animal Liberation Front, 2002). As an instance on the other side, the British Government sees such people as extremists or terrorists who undermine society's economy, and who harass and threaten those involved in lawful business and research. In July 2004 the British Government therefore declared that it would intensify its efforts to 'stamp out' illegal environmental activities (Home Office, 2004). The conflict over environmental values has, in Britain, even gone so far that activists are to face prosecution under terror laws aimed at alQaeda supporters (The Times, 2005).

The number of physical violations is not large and they are carried out by a small and marginal group of citizens. But the consequences can be considerable in terms of both money and violated people. When we hear about them in the Scandinavian countries, they often have to do with destroyed excavation vehicles, activists chained to cranes, or destroyed laboratories that experiment on animals. The main purpose of such activities is to put environmental ethics on the agenda - in which these actions, whether approved or not, certainly succeed. More common, however, are environmental conflicts that do not result in property damage but rather in violated people, distrust, and time- and cost-demanding processes of planning. These conflicts are significant in numbers but have a smaller magnitude, in the sense of media coverage or damaged property. Examples of such more frequent conflicts can be found in projects related to road construction, water management or urban development. They affect people through decisions or even proposals for new nature reserves or highways, limitation or permission regarding the driving of scooters, or concern that children can drown in an urban constructed wetland. Without presenting an endless list of conflict areas that can occur, it may easily be concluded that, as long as societies produce plans and projects, they will also produce conflicts.

Conflicts are generally viewed as undesirable, and still we have great difficulties in imagining a society free from conflicts or violations. Even in a perfectly constructed world, free from conflicts, as in Ira Levin's novel This Perfect Day, one can question whether it is really desirable to live in such a society. However, the fundamental desire to avoid conflicts is profound. This can even be seen in early writings such as Machiavelli's Il Principe, which normally is associated with Mussolini's fascists, who were not famous for their humanism or concern for individual needs and well-being. Today the major question is not whether conflicts may lead to something positive, which they can do, but rather how we can avoid conflicts. Hence, it is not surprising that planning theories used today relate in some way to conflicts as a problem and attend to methods of reducing them. This applies to synoptic planning theory as well as to communicative planning theory. These 
theories are the scientific foundation of environmental evaluation methods used in impact assessments. Looking at the spectrum of available methods developed, it is therefore important for the individual planner, manager or engineer to know how a chosen method will affect different stakeholders. This, of course, is also important when conducting an environmental assessment.

\section{Conflicts in planning theory}

Some authors, such as the social psychologists Rubin et al. (1994), understand conflict as a perceived divergence of interest, or a belief that the stakeholders' current aspirations cannot be achieved simultaneously. In relation to environmental planning and management, conflicts can be perceived as contrariety between stakeholders regarding values, interests, personal qualities, professional argument or role. Conflicts described as value conflicts are e.g. disputes about animal rights, human health, preservation of biotas, or threatened symbolic values (as with the whiteheaded eagle). Conflicts over interests are understood as disputes over e.g. water access, land use or monetary profit. Most conflicts related to environmental issues probably belong to this category.

Even if it is common that economic interests threaten ecological or aesthetic values, it should be added that there are often conflicts between environmental values and/or environmental interests, for example between environmental protection and nature conservation. Further, it is possible to place power struggles in this category, since these struggles are about attaining a better position for promoting one's interests in a future situation. Also, environmental conflicts that originate from class or 'ethnic' confrontations are related to issues of power and interests. These confrontations have their source in social structures and may result in (what many would regard as) an unjust distribution of environmental quality, such as green space close to high-income areas and toxic deposit sites close to low-income areas (Brulle, 2000).

In communicative planning theory, communication between parties is vital in order to accomplish a dialogue, in opposition to an information-oriented process, which sometimes is understood as 'one-way communication' (Forester, 1980; Healey, 1992; Sager, 1994). A dialogue has, according to its spokesmen, several advantages. It emphasizes mutual learning, where people's self-esteem, values and needs are considered as important as the 'instrumental' results of the plan or project (Hudson, 1979). The effects of the dialogue should therefore be increased empowerment and development of trust, with fewer conflicts as a natural outcome. Some go as far as to state that conflicts are resolved by a mutual desire to reach consensus, whereas some believe that conflicts are natural and permanent and only reflect the pluralism in society (as in incremental planning theory). The rationale for dialogue, according to several researchers, is that this will, if not remove conflicts, at least reduce their number and magnitude.

In this context it is interesting to add that it is often suggested that the reason why politicians in Sweden introduced public participation into the Plan and Building Act was that it was seen as a way of achieving a consensus, thereby improving the efficiency of the planning process and avoiding time-consuming conflicts. Public participation, however, is often expressed in terms of making suggestions or complaints about plans that have already been approved (see e.g. in Valves (1999) analysis of an infrastructure plan). Public participation therefore has, in reality, the ambition not of integrating public values into a plan, but rather of legitimizing the plan through 'one-way communication' (Killingsworth and Palmer, 1992; Throgmorton, 1993). Or as Firth put it:

Public agencies have been moving in the direction of meaningful public participation for many years. The results have been promising, but the 'disconnection' continues. Public 
agencies continue to develop alternatives that are presented to the public for 'input'... However, this practice does not demonstrate inclusion of public values. (Firth, 1998:329)

This use of public participation is therefore more in line with synoptic planning theory, which does not emphasize conflict as an important issue. Generally, synoptic planning theory with its technocratic perspective sees communication with the public as something that is needed to legitimize a project or to create acceptance for it. The rationale is that experts prioritize interests more efficiently, and/or that involving the public would only benefit stronger interest groups at the expense of less well articulated groups. Snell and Cowell (2006) found in their work on scoping in environmental assessments that the public often was excluded to avoid delays and confusion, and that consultants strived for efficiency by: “...expedite decision-making processes as far as possible, protect client relationship and manage objections" (Snell and Cowell, 2006:374). It can be added that a synoptic-influenced manager or planner may emphasize public participation, but in this case it is not about communicating values or interests, but rather to explain all the advantages of the suggested project, so that most people will understand the latter's rationality. The opponents, therefore, represent a group that is 'negative to development', or people who only care for their own interests (Sager, 1994).

\section{How stakeholders and interests are included in evaluation methods}

In the process of making an environmental assessment, a set of methods is applied. Different methods are used to define problems, to make models and interpretations of effects or risks, and to communicate the results. There are also numerous works on this subject (Wathern, 1988; Barrow, 1997). The basic and uncontroversial idea is that 'value-neutral' experts use scientific methods to find the most important effects that different alternative solutions have on the environment. But in a perspective of conflicts, it is notable that conflicts often appear at the stage of problem formulation when alternatives are chosen and consequences evaluated, due to different interests and values among stakeholders. Below I will make a brief overview of more or less well-known evaluation methods, and relate them to the discussion of dialogue vs. the information-oriented approach.

The Environmental Evaluation System (Dee et al., 1973) and most indicator methods are aggregated methods, primarily based on natural sciences, and characterized by several features of 'technological thinking' (Miller, 1985), viz. empiricism, objectivism, reductionism and quantification. In these kinds of methods, experts make the evaluation. Then there are methods such as costbenefit analysis (CBA) that combine the aggregated approach with information on people's willingness-to-pay. The result of willingness-to-pay is generalized so that it can be used for different purposes. In this way it serves as an abstract and context-free instrument, which is also one of the reasons why it has been extensively criticized (Holland, 1997), besides the fact that many believe that it has a democratic deficit (Söderbaum, 1998). In contrast to this approach, methods have been developed to take the local social context into account, such as the Panel Evaluation Method (Stauth et al., 1993) where both experts and representatives of the public are involved in the evaluation process. Compared with CBA, no generalization is made and a panel is designed for each evaluation and project. Other methods, such as the Leopold or Sondheim matrix, relate differently to opinions although both are defined as matrix methods. In the Leopold matrix (Leopold et al., 1971) there is a team of experts who evaluate each alternative. In Sondheim's method, however, the evaluation group consists of representatives from industries, politicians and NGOs (Sondheim, 1978).

Obviously there exist different strategies and assumed benefits of using communication to improve the outcome of any plan or project. The evaluation methods above can be placed on a 
continuum consisting of two contradictory positions. One is in favor of general communication between stakeholders, seeing communication as a deliverer of empowerment and knowledge (as in communicative planning). The other sees communication with non-experts as a waste of time and money, and a play for the gallery (as do some synoptic-oriented planners). If we want to use methods that reduce/prevent conflicts and promote development of trust, we should, according to the arguments above, choose evaluation methods that are more oriented towards communication.

But what about the characteristics of communication - is it enough if stakeholders communicate? Probably the form and substance are vital ingredients if communication should reduce conflicts. In the following sections I will therefore first explore the form of communication, where form is understood as rationality. Secondly, I will explore the substance of communication, i.e. what we should communicate about. Worth emphasizing, however, is that democracy and institutional issues are important to reduce conflicts, e.g. that documents and process must be transparent, that stakeholders ought to have some influence, and that the assessment must follow a process according to state laws.

\section{The form of communication: a critical reflection}

Max Weber (1947) defined four types of individual action that can be found in social behavior. Two forms are identified as rational and two irrational. An instrumental or functional rationality (Zweckrational) is focused on considerations of the link between means and ends. It is about calculating the possible outcome (costs and benefits) from available means and relating this to chosen ends. These ends ought to be unambiguous and clearly formulated goals, or a set of values, which are clearly formulated and logically consistent. Further, these ends are chosen by the stakeholder her/himself. It is, in other words, about defining ends, calculating and considering consequences, i.e. teleological ethics. The other form of rationality is absolutist or value rationality (Wertrational), which involves "a conscious belief in the absolute value of some ethical, aesthetic, religious, or other forms of behavior, entirely for its own sake and independently of any prospects of external success" (Weber, 1947:115). In value rationality there is no space for calculations about means and their effects, since the 'action' itself is the only thing that matters. The focus is on the act independently of the consequences, i.e. deontological ethics. Absolute values could be duty, honor, a religious calling, or personal loyalty. Examples would be the captain who prefers going down with his ship to leaving with a lifeboat, and the draft resister who chooses to go to prison instead of bearing arms.

Irrational actions are identified as affective and traditional. Weber here often uses the words 'meaning' and 'motive' in relation to rationality. If there is no motive, an act cannot be defined as rational. An affective action is then based on the emotional state of the person, rather than in the rational weighing of means and ends. For example, it may be an uncontrolled act, as in an outbreak of anger that has been provoked by jealousy, injured pride or an insult. However, Weber writes that the boundary of this category is close to rational acts, depending on how meaningful the act is. Its similarity to value rationality is that the meaning of the act lies not in the achievement, but in the act in itself. A traditional action is guided by customary habits of thought and long practice. The level of self-consciousness is not high in such acts.

But before concluding the description of Weber's rationality, a question must be raised about the substance of the end. Can, for example, cruel acts or war be rational? According to Forester (1985), instrumental action must address issues of common desirable goals and norms. The problem with this is whether it can be more rational to pursue certain objectives rather than others. To hold that the objective of an action must be judged before being defined as rational, one must 
believe that values are objective and that there is a moral theory which is correct. But since humans have different perceptions of the world and different value-systems, the defender of such a position has to define what is right or wrong, good or evil. Recalling the issue of environmental activism vs. governmental responsibility described in the introduction, which side acts rationally? In my view, they both do. Weber, too, when defining rationality, did not include any argument that a social act should be judged by the content of an end or goal to be considered rational.

In planning literature it is sometimes put forward that a planned action is rational, but this implies that some planners and decision-makers act irrationally. It may however be argued that the concept of irrationality has limited value in the context of environmental assessments, since everyone wants to be rational. Few would even hold those who follow their 'absolute values' such as duty, honor, and religious belief - for example, draft resisters - to be irrational. As also Weber writes, one must proceed from the goals of each individual to judge whether an action is rational, and a draft resister certainly acts on his or her beliefs. If the criterion of being rational is that one tries to promote one's interests, beliefs and values, I believe that all human actions are rational. On the other hand, if one defines rationality as the act of making decisions and judgments that are based on reason rather than emotions, and not as e.g. Weber defines it in terms of 'calculating' the possible outcome from available means and relating this to chosen ends (where ends could be a set of values), then it becomes very difficult to say that all human actions are rational, since human action is driven largely by emotions such as love, joy, pride and fear, which I prefer to regard as positive. In this case the conclusion would rather be the opposite - that humans generally are irrational beings. Thus the interpretation of the concept of rationality becomes substantially dependent on our perception of the terms 'reason' and 'emotion'. Is it, for example, rational to say: "Let us save this wood because it's beautiful"? I believe so.

Following this argumentation, Weber's definition of instrumental rationality (teleological ethics) sounds reasonable. However, communication in this form is far from the communication advocated in the communicative planning theory, which foster deontological ethics. As I see it there is three problems with how this theory deals with rationality, which I will shortly describe:

1. The existence of an ideal dialogue: asymmetric power. Communication, according to communicative planning theory, should be a communicative action (or value-rational as in Weber's definition). This belief follows a deontological ethic, which is the opposite of a teleological ethic. According to Habermas' (1990) theory of communicative action, communication ought to be in the form of an 'ideal dialogue'. That is to say, the dialogue must be open, everyone should be able to start or stop a discussion whenever they wish, and every argument is to be judged equally. A common objection to communicative rationality is to question the existence of an 'ideal dialogue'. Foucault, among others, states that there is never a powerless situation among stakeholders. Asymmetric power relations, level of knowledge about the planning process, and scientific background affect the possibility to succeed in a communicative process.

2. Accepting the best argument. But even if we had 'open' communication, should we end up in every case with a consensus among stakeholders? Habermas' theoretical foundation is based on cognitivism, which assumes that people inevitably search for and accept rational arguments (Pløger, 2001). A dialogue should end in a reason-based consensus, consisting of trust, solidarity, non-manipulation and fairness. However, the main problem is generally not the correctness of an argument or of data, but how the question or problem is defined in the first place. As in the example of environmental activism vs. governmental responsibility, there are many situations where the conflict between people is based on different values, which may result in an acceptance but seldom in consensus. 
3. Goal achievement as a by-product. In communicative planning theory, it is the social act of communication that is to be emphasized. Planners should communicate as closely to an 'ideal dialogue' as possible. This approach is clearly displayed by Sager (1994:7): "the development of mature personalities has an intrinsic value in communicative rationality (consisting of truth, rightness and sincerity), whereas goal achievements are by-products". To me, however, it is unjustifiable that professionals do not have the ambition to take consequences into consideration.

\section{The substance of communication}

What should we communicate about? Most decision-makers and practitioners working with environmental assessment do not believe, at least on an ideological level, that it is enough for a project to fit the given framework of technological, economic and jurisdictional criteria. However, there are numerous examples when this is not the case, resulting in front-page headlines and more or less successful statements from responsible politicians or press secretaries. At least the fact that actions to benefit e.g. economic interests can harm or violate other stakeholders, who in turn can affect one's own interests, is a reason to consider ethics. This is partly why global companies are concerned with e.g. working conditions of employees in the South World or environmental issues. It can simply ruin their image not to be concerned. In other words, it is wise to consider people's values in all decision-making. But beside ethic considerations, there seems to be other arguments for communication about values in environmental assessments. The importance of starting with defining and communicating values in a decision situation is advocated by Keeney (1996). He writes that the normal mode of decision-making is to focus on alternatives, and then on objectives in order to evaluate these alternatives. He refers to this standard problem-solving approach as alternativefocused thinking. According to Keeney, this means thinking backwards, because it puts identifying alternatives before articulating values. It is focused on solving decision problems instead of creating alternatives. Instead the focus should be on formulating strategic objectives and a means-ends network, which Keeney defines as value-focused thinking. He writes that the main role of alternatives is not to solve problems, but to fulfill values. But value-focused thinking has also the advantage of not only improving the creation of alternatives, but also identifying decision situations.

While Keeney emphasise on values and objectives, other believes in term of stakeholders' interests, which is also strongly linked to both value and objectives. The idea that interests are fundamental in all planning activities is put forward in numerous handbooks of Environmental Conflict Resolution (Lewicki et al., 2003; Daniels and Walkers, 2001), theories such as Principled negotiation (Fisher et al., 1992), and in disaggregated assessment methods such as Positional Analysis (Söderbaum, 2000). Not seldom, physical planning is seen as the art of handling interests and conflicts between interests. However, in many environmental assessments consequences of selected alternatives are presented as an altered state of the environment, shown through a set of environmental parameters and sometimes by maps and pictures. It is important to recognize that behind every parameter there is a human interest. Behind a $\mathrm{dB}$ number there are satisfied or disturbed humans, behind $\mathrm{CO}_{2}$ emissions there are worriers about flooding or drought, behind statistics on water pollution there are fishing interests, and so on. The problem with these parameters standing alone is that they hide the different interests at stake. They give one the impression that the result of the assessment is an objective result, when in fact it is more or less intrasubjective. Valid critique may therefore be directed at how the problem is defined; what alternatives are investigated; or which issues that are addressed. To recognize this is to take a step towards an understanding of environmental conflicts and to achieve a better acceptance of plans and projects among stakeholders including the public. Therefore, this ought to be an important 
complement to traditional effects on the environment expressed in load, pressure, responses or other ecological concepts.

\section{Environmental assessments, conflict and communication}

This article began by showing the differences in perception among environmental activists and governmental representatives. These stakeholders are both convinced of the rightness of their actions, and therefore display a value-based conflict situation that is seldom resolved by a dialogue. We have to accept that society consists of people with different interests and values, which inevitably lead to numerous conflicts.

Through communication about values and interests associated with any implementation of plans and projects, these can be defined and displayed. This in turn will lead to more knowledge of active and passive stakeholders, values and interests associated and about the problem. With this knowledge there is a greater possibility for involved stakeholders to develop creative problemsolving to find common gains, a win/win solution, environmental compensations and central environmental values. But this will also increase democracy regarding e.g. influence, transparency and trust, and prevent conflicts of interests. The idea is not to hide or erase conflicts, but to accept conflicts as natural and a starting point for communication. Therefore, when conducting an environmental assessment, methods that is based on communication about values and interest ought to be preferred.

\section{Acknowledgements}

The author would like to thank Prof. Peter Söderbaum and Dr. Ane Kirkegaard for comments on earlier drafts on this paper.

\section{References}

Barrow CJ. Environmental and social impact assessment: an introduction. London: Arnold; 1997.

Brulle RJ. Agency, democracy and nature. Cambridge, USA: MIT Press; 2000.

Daniels SE, Walkers GB. Working through environmental conflict, the collaborative learning approach. London: Praeger; 2001.

Dee NJ, Baker N, Drobny, Duke K. An environmental evaluation system for water. Resour Plan Water Resour Res 1973;9 (3):523-35.

Firth LJ. Role of value in public decision-making: where is the fit? Impact assessment and project appraisal, vol. 16 (4). Surrey, USA: Beech Tree Publishing; 1998. p. 325-9.

Fisher R, Ury W, Patton B. Getting to yes: negotiating an agreement without giving in. 2nd ed. London: Random House; 1992.

Forester J. Critical theory and planning practice. J Am Plan Assoc 1980:275-86.

Forester J. Practical rationality in planmaking. In: Breheny M, Hooper A, editors. Rationality in planning. London: Pion; 1985.

Habermas J. Kommunikativt handlande: texter om språk, rationalitet och samhälle. Göteborg: Daidalos; 1990.

Healey P. Planning through debate: the communication turn in planning theory. Town Plan Rev 1992;63(2):143-62.

Holland A. The foundations of environmental decision-making. Int J Environ Pollut 1997;7(4).

Home Office, 2004. Animal welfare-human rights: protecting people from animal rights extremists. [Internet] Available from:http://www.homeoffice.gov.uk/docs3/humanrights.pdf [Accessed 17 August, 2004].

Hudson BM. Comparison of current planning theories: counterparts and contradictions. J Am Plan Assoc 1979;45: 387-98.

Keeney RL. Value-focused thinking: identifying decision opportunities and creating alternatives. Eur J Oper Res 1996;92:537-49. 
Killingsworth, M.J. \& Palmer, J.S., 1992. The Environmental Impact Statement and the Rhetoric of Democracy. In Benton, L.M. \& Shot, R.J. (2000), Environmental Discourse and Practice. Blackwell Publisher, Malden, USA.

Leopold LB, Clarke FE, Hanshaw BB, Balsey JR. A procedure for evaluation environmental impact. Geological survey circular, vol. 645. Washington: United States Department of the Interior; 1971.

Lewicki RJ, Gray B, Elliott M. Making sense of intractable environmental conflicts: concepts and cases. Washington: Island Press; 2003.

Miller A. Technological thinking: its impact on environmental management. Environ Manage 1985;9(3):179-90.

North American Animal Liberation Front, 2002. 2001 year-end direct action report, January 12, 2002 [Internet] Available from:http://www.animalliberation.net/news/02/020116m1.html [Accessed 18 August, 2004].

Pløger J. Public participation and the art of governance. Environ Plann B Plann Des 2001;28:219-41.

Rubin JZ, Pruitt DG, Kim SH. Social conflict. New York: McGraw-Hill; 1994.

Sager T. Communicative planning theory. London: Ashgate; 1994.

Snell T, Cowell R. Scoping in environmental impact assessment: balancing precaution and efficiency? Environ Impact Asses Rev 2006;26:359-75.

Sondheim MW. A comprehensive methodology for assessing environmental impact. J Environ Manage 1978;6:27-42.

Stauth R, Sowman M, Grindley S. The panel evaluation method: an approach to evaluation controversial resource allocation proposals. Environ Impact Asses Rev 1993;13:13-35.

Söderbaum P. Economics and ecological sustainability: an actor-network approach to evaluation. In: Lichfield N, editor. Evaluation in planning. Boston: Kluwer Academic Publishers; 1998. p. 51-71.

Söderbaum P. Environmental management and decision-making: a political economics approach. Ecological economics: a political economics approach to environment and development. London: Earthscan; 2000. Chapter 6.

The Times, 2005. Terror laws will apply to animal rights lobby, October 25, 2005 [Internet] Available from:http://www. timesonline.co.uk/article/0,2-1841452_1,00.html [Accessed 25, October 2005].

Throgmorton JA. Planning as a rhetorical activity. J Am Plan Assoc 1993;59(3).

Valve H. Frame conflict and the formulation of alternatives: environmental assessment of an infrastructure plan. Environ Impact Asses Rev 1999;19:125-42.

Wathern P. Environmental impact assessment - theory and practice. London: Unwin Hyman Ltd; 1988.

Weber, M., 1947. The theory of social and economic organization. Ed. with an introduction by Talcott Parsons. Sixth printing, Free Press, New York, February 1969. 